\title{
3 THE MARGINALIZATION OF WOMEN IN OBSTETRICS
}

The birth chamber was considered the exclusive domain of women, at least up to the eighteenth century. ${ }^{1}$ Lyings-in were thus exempt from the male control that extended over almost all other aspects of a woman's life. And yet, as we have seen in the representations of Caesarean birth, for operative deliveries men did enter the birth chamber, and they did so earlier and more consistently than has been recognized in the past. As the evidence shows, midwives were systematically excluded from the Caesarean operation starting about the beginning of the fifteenth century. This exclusion was but the first step in a long series of exclusionary and controlling measures aimed at women in medicine. The marginalization of midwives must be seen in the wider context of misogynistic attitudes in the medieval medical profession and in society at large. The removal of women from positions of relative autonomy to positions under the control of male medical faculties and city administrations becomes especially clear in the fields of obstetrics and gynecology. The independent and competent women practitioners of the earlier Middle Ages are replaced, in the later Middle Ages, by women caught up in a web of medical regulations and municipal ordinances aimed at either prohibiting their practice altogether or at least placing them under total control. Since Caesarean birth was one of the first obstetrical procedures that was lost to female practitioners, the circumstances of this operation can be used as a point of departure for a study of developments in the history of women in medicine. In medicine as well as in historiography the repercussions of many of these developments can still be felt today. 


\section{Misogynistic TRENDS In THE Historiography OF MEDICINE AND WITCHCRAFT}

Medieval misogyny took on so many different forms and was such a constant in the works of male writers that Christine de Pizan, in her Book of the City of Ladies (I4OS), felt compelled to reflect on the discrepancies between the strangely unanimous opinions of male authors and her own observations:

They [male authorities] all concur in one conclusion: that the behavior of women is inclined to and full of every vice. Thinking deeply about these matters, I began to examine my character and conduct as a natural woman and, similarly I considered other women whose company I frequently kept, princesses, great ladies, women of the middle and lower classes, who had graciously told me of their most private thoughts, hoping that I could judge impartially and in good conscience whether the testimony of so many notable men could be true. To the best of my knowledge, no matter how long I confronted or dissected the problem, I could not see or realize how their claims could be true when compared to the natural behavior and character of women. ${ }^{2}$

Could so many notable men be wrong? Were women not only the instigators of all evil deeds, as the witch-hunters would have it, but also unsuited for responsible positions in society? Or should we say "and therefore unsuited for responsible positions in society"? These questions lie at the center of the inquiry into the lives of medieval midwives and female practitioners who were attacked on two fronts at once. On the one hand, they were the victims of the professionalization of medicine, which consisted largely in exclusionary measures directed at women and empiric healers. On the other, midwives and female practitioners were among the prime targets of the witch-hunts. Their knowledge in the areas of contraception and abortion endangered and often cost them their lives.

Much research has been done on the exclusionary practices of the medical profession and the link between the midwife and the witch established by medieval and Renaissance witch-hunters, but scholars have not always recognized exactly how these two areas intersect. The twof old denigration of midwives - by the medical establishment and the witch-hunters-was in fact inspired by a single goal: to discredit and marginalize female midwives and healers.

Understanding of this problem has been hampered by a male scholarly bias in the historiography of medicine as well as in that of witchcraft. 
Only recently have some of these problems been brought out into the open.

In 1971, Charles Rosenberg noted that "until comparatively recent times, most medical practice has been in the hands of informal, rural, semi-educated practitioners and such men and women leave few tracks in the archival sand. Thus the history of medical practice has tended to be the chronicle of a self-conscious and comparatively articulate urban elite."3 Needless to say, this elite was male and paid little attention to the history of women in medicine. Before the work of Mélanie Lipinska in 1900, women made few appearances in the historiography of the medical profession. Since it was this male medical elite (mostly physicians who wrote medical history in their spare time $)^{4}$ that was responsible for most of medical historiography, the history of medicine tended to become that of the medical profession, specifically that of the progress in that profession marked by a growing exclusiveness in education and admission to the ranks of licensed physicians. Thus the medieval developments of the medical guilds with their statutes and licensing procedures were hailed as the harbingers of the modern medical profession. ${ }^{5}$ The deficiencies of medieval medical practice, which were perpetuated through exclusionary measures (at the expense of often more reasonable "folk" medicine) are rarely seen in connection with-and even more rarely as the result ofthe new licensing procedures and statutes that marked the fourteenth and fifteenth centuries. Consequently our knowledge of what empirics, and especially women empirics, actually did is filtered through a screen of prejudices and modern notions of professional medicine.

The historiography of the witch-hunts as well was, until recently, male dominated, although not in the same way as that of the medical profession, which was, in a sense, writing the history of its own "guild." But even well-intentioned historians often lost sight of the fact that in the prosecution of witches the antiempiricist, misogynist, and antisexual obsessions of the church coincided.6 Thus Gregory Zilboorg sees the profoundly antifeminist Malleus maleficarum, a late fifteenth-century handbook for witch-hunters, as "an excellent modern textbook of descriptive clinical psychiatry ... if the word 'witch' were substituted by the word 'patient' and the devil eliminated."' For him, the victims of the witch crazes seem to have been more at fault than the persecutors. If mental illness played a role in the witch-hunts then surely it did so as much on the side of the prosecutors as on that of the prosecuted. As Anne Barstow has shown recently, the idea that women somehow brought the 
persecutions upon themselves pervades many of the modern accounts of the witch-hunts. 8 Thus Julio Caro Baroja concludes that "a woman usually becomes a witch after the initial failure of her life as a woman," implying that not only did women actually become witches but that they even chose to do so because of some deficiency in their lives, a last recourse for the "unfulfilled woman" as it were. 9 Similarly, Thomas Forbes downplays the perversity of some of the accusations leveled against women when he says, "we have seen how some midwives became involved in witchcraft." 10 Thus caution and an awareness of possible critical prejudices are necessary in approaching the areas in which the demotion of midwives has to be studied.

\section{The Professionalization of Medicine AND THE EXCLUSION OF WOMEN}

That male physicians or surgeons were not allowed in the birth chamber and performed no gynecological exams are two of the received notions in the history of obstetrics and gynecology. ${ }^{11}$ They were certainly true for most of the Middle Ages. In the famous trial of the female physician Jacoba Felicie in 1322, the defense counsel argued that "it is better and more seemly that a wise woman learned in the art should visit a sick woman and inquire into the secrets of her nature and her hidden parts, than that a man should do so, for whom it is not lawful to see and seek out the aforesaid parts.... A man should ever avoid and flee as much as he can the secrets of women and of her societies."12

In the antique and Arabic medical traditions, however, there are clear indications that men assisted in difficult births, that is, they performed embryotomies and possibly even Caesareans and had some functions in gynecology.

In the Hippocratic writings a male physician is mentioned as helping during a protracted birth as well as performing a gynecological exam by inserting a finger into the patient's vagina. ${ }^{13}$ The Roman medical writer Celsus (first century A.D.) also specifies that a male physician should perform embryotomies and internal version of the fetus. A male physician also examined women for bladder stones by inserting a finger into the patient's vagina or, if she was a virgin, into the anus.

In Soranus's Gynecology the male physician makes several appearances. The description of the causes for difficult labor includes this remark: "or through the inexperience of the midwife or the physician." Somewhat 
further he says, "In cases of difficult labor the physician should also question the midwife." Finally, he urges that midwives seek the assistance of a male physician for embryotomies. ${ }^{14} \mathrm{~A}$ male presence at difficult births thus seems to be taken for granted.

In the Arabic tradition, several passages in the writings of Abulcasis and Rhazes show men performing or assisting at procedures dealing with difficult births or some gynecological disorders. ${ }^{15}$ In a well-known story, Abulcasis mentions an operation for an abdominal tumor that he himself did on a woman. A bizarre aftermath of the operation was the emergence, through the scar, of the bones of several dead fetuses the woman had carried for years. ${ }^{16}$

Rhazes, in a passage in the Continens introduced by the term that always identifies his own original remarks, deals with the removal of the secundines by addressing his male reader: "If you need to use an iron instrument seat the woman on a chair and let there be a back to the chair." He then specifies that a male practitioner (mu'alij) should use an instrument not unlike the modern speculum to widen the vulva and the cervix. ${ }^{17}$ Rhazes also says that he himself performed an extremely painful gynecological operation in which the woman fainted. ${ }^{18}$

Abulcasis, unlike Rhazes, assigns the use of the speculum (of which he provides a sketch) to the midwife. ${ }^{19}$ Avicenna in his detailed instructions on the surgical extraction of dead fetuses also only addresses the midwife, although a male advisory function is not excluded.20 These references, especially for the works of Rhazes, signal a more or less extensive male participation in Arabic obstetrics and gynecology.

But in the medical writings of the medieval Latin West before the late thirteenth century nothing leads to the conclusion that men had functions in obstetrics and gynecology similar to those held by men in the Arabic tradition and in antiquity. Some of the earliest indications that men treated gynecological ailments have been found by Nancy Siraisi in connection with Taddeo Alderotti and his pupils in late-thirteenthcentury Bologna. Of Taddeo's one hundred eight-five consilia, or descriptions of recommended treatments, ten concern gynecological problems. ${ }^{21}$ Guglielmo of Brescia "treated both gynecological problems (if we can judge from the fact that he wrote on breast cancer and tumors of the breast on five separate occasions, and problems of sexual dysfunction)."22 Writing about a treatment does, of course, not necessarily mean that physicians actually used it, but Siraisi's evidence suggests that they did. 
Clearer on the question of the actual performance of an external gynecological exam is John Gaddesden's early-fourteenth-century Rosa anglica, which specifies that "ponat medicus vel obstetrix manus comprimendo os stomachi et ventrem" (the doctor or the midwife lays the hand on the stomach or belly to compress it). ${ }^{23}$ But the internal gynecological exam was still in the domain of the midwife. It is not until the early fifteenth century that a male physician, Anthonius Guainerius, alludes "to the possibility of a doctor conducting a pelvic examination on a female patient. ... In the chapter on sterility, he states that if examination is permitted to the physician, he can determine whether sterility is caused by excessive narrowness, width or tortuosity of the mouth of the womb."24 Caesareans, as we saw in the last two chapters, also started to be performed by men only in the fifteenth century.

Thus a complex picture of men's obstetrical and gynecological activities emerges. It seems that in the later Middle Ages men regained some of the functions they had performed in antiquity and the Islamic world, functions they had to wrest away from women who for centuries had been in control of obstetrics and gynecology and thus of their own bodies.

For many women internal gynecological exams evoke-and not necessarily only on a symbolic level-thoughts of the sexual control by men that they experience in their normal lives. In the vulnerable state of illness a woman may thus want to avoid any reminders of male domination. Very often, in fact, men were the cause of the ailments women had to seek help for, as in an extreme example of sexual violence in marriage that can be found in one of the miracles of the Virgin collected by Gautier de Coincy. ${ }^{25} \mathrm{~A}$ husband in Arras, after six months of futile attempts to deflower his young bride, finally, in a fit of rage, takes a knife and mutilates her sexually. When she complains to the bishop he counsels her to remain with her husband, for otherwise, he concludes, she would have no protector. This was, one hopes, an extraordinary case, but it shows nevertheless that a woman could expect little help from men in positions of control. (The woman of Arras is finally saved by the intercession of the Virgin Mary.) No wonder, then, that women had little desire to confide their "secrets," as the counsel of Jacoba Felicie put it, to men. And yet, in the fifteenth century, men make the first inroads into fields closed to them for centuries.

The period of the regaining of male control in certain areas of medicine coincided with efforts to establish medicine as a profession, with all the 
exclusionary measures this entailed. But more than a temporal coincidence is involved here, since the professionalization of medicine also led to a new self-definition of physicians, surgeons, and barbers and to a new competitiveness regarding areas of permitted activities and fields of competency. Midwives as well as female physicians and surgeons were the losers in this battle for prerogatives, and their disappearance from images of Caesarean section marks the beginning of the long struggle on the part of male doctors and the authorities to banish women from the realm of medicine.

The professionalization of medicine was closely linked to the rise of the universities and the establishment of medical faculties. For both Paris and Montpellier, the earliest references to a medical faculty can be found in the early thirteenth century, and the first extant medical regulations date from $1270-74 . .^{26}$ The granting of medical licenses was a complicated affair and took place in a biennial ceremony. The charters specified that no master could present more than two bachelors for the license at any one time, a proof that only very few students reached this last stage of their medical education. ${ }^{27}$

The growing exclusiveness of the medical profession led to the fragmentation of what had before been a more coherent body of medical practitioners. The sharpest competition and antagonism existed between university physicians and surgeons. From 1350 on, doctors required that all bachelors who hoped to receive a medical license had to take a solemn oath never to practice manual surgery. ${ }^{28}$ Consequently, the surgeons felt justified in creating their own corporation, the Collège de Saint Côme. The surgeons of Saint Côme competed for status with the university physicians. They wore the long robe to set themselves off from the lower surgeons (de robe courte), or the barbers. By 1390, the surgeons were recognized as "true scholars" by the university, and it seems that at the beginning of the fifteenth century the surgical corporation gained the privilege of participating in lectures at the medical faculty of the university. ${ }^{29}$ But there was never any real peace between the two groups, for at the end of the century the university doctors banded together with the barbers against the surgeons. ${ }^{30}$ As a means to woo the barbers, the learned physicians even allowed the use of the vernacular at autopsies. The surgeons abandoned some of their functions to the barbers "on the grounds that such operations would be degrading to surgeons." 31 At the beginning of the sixteenth century, finally, a semblance of peace was established between the different professional groups, but it did not last 
and the conflicts extended well into the eighteenth century, as Wickersheimer pointed out in his introduction to the Commentaires. 32

The turn from the fourteenth to the fifteenth century, then, marked the period of the most intense efforts on the part of the surgeons to gain a status similar to that of the university physicians. Caesarean sections did not belong to the type of operation scorned by surgeons intent on their advancement. This became clear in the illustrations discussed in Chapter 2: all the male surgeons in them wore the long robe of Saint Côme. The efforts to improve the surgeons' status also coincided with the first reports of successful Caesareans.

Oswald Feis discovered in the archives of Frankfurt a document from I4II that contains a petition to the city council on behalf of a poor old midwife, Mother Guetgin, who was imprisoned for mental illness. The petitioner, a man named Jost von Pern, implores the council to release the midwife. In support of his plea he lists her many accomplishments, the most remarkable being seven Caesarean sections that she had performed with "success for mother and child." 33 Given the conditions of abdominal delivery at that period the story sounds unlikely. Nevertheless, it proves that at least the midwife had a reputation of extraordinary skill in this field. It also proves that news of such operations circulated in the early fifteenth century. What better moment, then, for male surgeons to claim a new function for themselves, one that now afforded at least the possibility of gain and prestige?

The first report of a male surgeon having himself performed the operation, that of Piero d'Argellata, postdates the Frankfurt report by only a few years. And it is exactly for that period, of course, that the illuminations discussed here faithfully chronicle this transition.

The first official measures restricting the role of women in medicine came from the university faculties, but guilds and corporations did not prove too receptive toward medical women either. Nevertheless, women persisted in trying to find a place for themselves in the many branches of medieval medicine.

Since women were barred from the universities except in Italy, they could not become physicians; but other possibilities were open to them, and they performed a wide variety of healing functions. In medieval French documents many different titles for women in medicine have been recorded: fisicienne, miresse, chirurgienne, barbière, médecine, guarisseuse, norrice, sage-femme (or ventrière), and vieille femme. ${ }^{34}$ Fisiciennes, miresses, and médecines treated internal ailments, whereas the chirurgienne, 
or surgeoness, was in charge of major operations. The barbière could perform minor surgery as well as toothpulling, phlebotomy, and hairdressing. Guarisseuse and vieille femme are vaguer terms and probably designate empirics or faith healers. Sages-femmes, or ventrières, assisted women during childbirth.

For the period between the twelfth and the fifteenth centuries in France, 12I names of women in medicine have been recorded. ${ }^{35}$ Of these, about one-third were midwives (including the aleresses, or wet nurses) and all of those lived in the fourteenth and fifteenth centuries. Chirurgiennes and barbières are mentioned in the twelfth century. For the second half of the thirteenth century, fifteen women surgeons and barbers are known by name. ${ }^{36}$ It is interesting to note that midwives are mentioned by name only in the later centuries. That is, as long as women were not categorically excluded from other branches of medicine, midwives were not explicitly mentioned. Names were listed only for those women who were surgeons or physicians. But once women were marginalized in the more prestigious medical and surgical professions, actual names of midwives start appearing.

In France, the corporations of surgeons did not officially ban women from surgical practice until the edict of Charles VIII in I484. But, as Danielle Jacquart points out, in most cases women were allowed to take over the office of surgery only if their surgeon husbands had died and the widows did not remarry. ${ }^{37}$ In theory, widows of surgeons were legally allowed to practice until $1694 .{ }^{38}$ In England, a Guild of Surgeons was formed in 1540 , and one of their statutes specified that "no carpenter, smith, weaver, or woman shall practice surgery." 39 Occasionally, women practiced surgery together with their husbands, as did, for example, a certain Guicharde of Lyons whose name is recorded in the year 1267.40 Several fifteenth-century women successfully assisted their surgeon husbands, but when in $\mathbf{I} 462$ the Rheims surgeon Jean Estevenet wanted to enter a monastery and hand over his practice to his wife, the surgical masters of the city took her to court. ${ }^{41}$

One of the statutes of the University of Paris, proclaimed in I3II, addressed itself to both female and male surgeons: "No surgeon or apothecary, man or woman, shall undertake work for which he or she has not been licensed, or approved."42 But what sorts of skills these surgeons had to have is not quite clear, since documentation on the education of surgeons is very sparse. ${ }^{43}$ It is generally believed that the skills subject to approval by a surgical committee were learned by apprenticeship. Surgi- 
cal treatises are one source of information, of course, but they cover mostly the more complicated functions of a surgeon, and because of their often theoretical nature (especially after the thirteenth century) they probably do not reflect the day-to-day activities of medieval surgeons.

In any case, the surgeoness existed, and we have proof of one of her functions, performing Caesareans, in figures 8, 9, and Io. Women could also perform "minor operative procedures, like cupping." 44 In manuscript Sloane 6, folio 177 (fifteenth century) one can see a woman applying cups (to draw blood) and a cautery. ${ }^{45}$ The patient is a man, but in other illustrations in the manuscript the same treatment is applied to female patients.

For women physicians it was very difficult to gain professional approbation. As we saw above, the rise of university medicine made it impossible for women (outside of Italy) to obtain the training necessary for a medical degree. Nevertheless, women practiced medicine in all its forms, including internal medicine, the domain generally reserved for university physicians. Records exist of at least two women who managed to earn the titles of royal physician or surgeon. "Magistra Hersend physica" was one of the physicians of Louis IX and followed him on the crusade in 1249 . Her function seems to have been to attend to the queen and other women who accompanied the crusaders. ${ }^{46}$ She survived the crusade and was still listed in Parisian records (together with her husband, Jacques, apothecary to the king) in 1259 and 1299 . The second case is that of Guillamette de Luys, who appears in a record of 1479 when Louis XI granted her a reward. ${ }^{47}$ But women like these were probably the exceptions and too little is known about their education and connections to decide how extensive their functions really were.

More representative of the fate of women healers is the case of Jacoba Felicie. Her trial for unlicensed practice, described in great detail by Pearl Kibre, illustrates how women, at least until they were dragged to court by jealous fellow doctors, could get around official proscriptions. Without explicitly masquerading as a physician, Jacoba gained the confidence of her patients by her competent examinations and diagnoses. She did not demand money until the patient was cured, a practice that probably was unusual for male and female practitioners alike. Several witnesses stated they had turned to Jacoba after a number of licensed physicians had been unable to cure them. But all the support Jacoba received from her patients did no good, and in the final verdict she was found "guilty of 
willfull disobedience" and, under threat of excommunication and a fine of sixty Parisian pounds, was barred from practicing medicine. ${ }^{48}$

Trials for charlatanism and unlicensed practice continued for the next two centuries, and the defendants were probably not always such capable medical practitioners as Jacoba had been. The medical faculty at Paris gained papal support in their fight for total control over medical practice. ${ }^{49}$ As a result of the relentless prosecution of unlicensed healers and of the increasing difficulties for women to obtain a medical education that would then enable them to get licenses, the presence of women in medicine dwindled until Estienne Pasquier could state in the sixteenth century that "one still finds some learned women who, by a special inclination, are drawn to the study of the natural sciences and even of medicine, but very few practitioners."50

For midwives, the case was different, of course. General obstetrics did not interest male surgeons until the eighteenth century. Thus midwives continued to assist at births and to perform gynecological exams. What kind of qualifications did they have?

When Soranus answered his question "Who are the best midwives?" he had in mind an ideal type of midwife, probably as rare in antiquity as in the Middle Ages. ${ }^{51}$ Here are some of the qualifications he required of a midwife: "A suitable person will be literate with her wits about her, possessed of a good memory, loving work, respectable ..., sound of limb, and, according to some people, endowed with long slim fingers and short nails at her fingertips. She must be literate in order to be able to comprehend the art through theory too. .. . Now generally speaking we call a midwife faultless if she merely carries out her medical task; whereas we call her the best midwife if she goes further and in addition to her management of cases is well versed in theory." Soranus insisted that the midwife should be competent in all areas of obstetrics and gynecology. He did not think it necessary that a midwife should have had children herself. However, she must be sober and able to keep secrets; she "must not be greedy for money, lest she give an abortive wickedly for payment; she will be free from superstitition." Thus Soranus specified both medical and moral qualifications for his ideal midwife, but the emphasis was clearly on the midwife's medical competence.

Soranus's high medical requirements and especially his insistence on the midwife's literacy no longer fit the midwife's portrait once we enter the Middle Ages. Little is known of the earliest midwives in the medieval 
north. The word heveamme, which developed into modern German Hebamme (midwife), is attested in two German poems from the twelfth and thirteenth centuries that allude to obstetrical examinations performed by these women. ${ }^{52}$ In France, the oldest term for a midwife was pentriere, attested for the first time in $\mathbf{1 2 9 2 .}{ }^{53}$ In Italy, the mulieres Salernitanae may have been midwives. ${ }^{54}$

Given the low level of female literacy, even toward the end of the Middle Ages, most midwives must have learned their skills by apprenticeship. 55 There were also many manuals intended for their use. The best known among these manuals were the works of the Trotula tradition, which were translated into many languages. ${ }^{56}$ But there was also a large number of anonymous treatises, such as the one analyzed by Pansier in "Un Manuel d'accouchements du XVesiècle," which concentrated on fetal positions and how to correct them. More elaborate texts appeared in the fifteenth and sixteenth centuries, some of them meant for midwives, such as Roesslin's work, Der Swangern Frawen, and some of them addressed to men, such as Anthonius Guainerius's Tractatus de matricibus. 57

But how could midwives profit from these written instructions? In some cases, groups of literate people may have instructed illiterate practitioners. ${ }^{58}$ For late medieval Nuremberg, Merry Wiesner has shown that the city council assumed that midwives could read; ${ }^{59}$ it is therefore not warranted to conclude categorically that midwives never came into contact with the manuals designed for their instruction.

Another source for the analysis of the midwives' duties and areas of competency are the canons of various church councils and the regulations for municipal midwives that appeared in the later Middle Ages. Those church councils that produced canons dealing with Caesarean sections placed special emphasis on the midwives' skills and responsibilities. Midwives were forced to make complex decisions on possible surgical delivery and baptism; any misjudgment on their part had serious consequences not only for mother and child but for the midwife's future as well. ${ }^{60}$ Thus the texts of the councils give us one of the earliest testimonies regarding medieval midwives, since they predate any ordinances and regulations on midwifery by several centuries. On the whole, the relevant canons seem to place more trust in the midwife's ability than the later regulations, which are largely of a restrictive nature.

In Germany, regulations of midwifery appeared about a century earlier than in France. They were characteristic of the large independent towns with strong municipal governments. Midwives were first mentioned in 
Nuremberg in 138I and "appeared as sworn city officials in the Amtsbüchlein, the list of all occupational groups required to take an annual oath before the council, in 1417." 61 But the first surviving Hebammenordnung comes from Regensburg, a town in Bavaria, and dates from $1452 .{ }^{62}$ The rationale for the issuing of statutes for midwifery was the "lack and departure" of good midwives and the resulting disorder in the care of women. Candidates for midwifery were examined by a committee of honorable women of the town. To ensure proper care for rich and poor women alike, midwives were required to visit and assist any pregnant woman regardless of her ability to pay. Any delinquent fees would be made up by the honorable townswomen. The only women the midwife was not obliged to care for were Jewish mothers. The Ordnung also insisted on sobriety and on patience: no woman, especially if she gives birth for the first time, should be hurried. Forceful dilation, pushing on the stomach to hasten the birth, and urging women too early to help push out the child seem to have been common practice among midwives. As for the Caesarean section, in case the mother dies the midwife is to perform it immediately; no delay or excuse will be accepted. Should both mother and child die, an inquiry will have to show that neglect was not the cause of the disaster. In any case, midwives should use their failure as an opportunity to learn. But if they bury the mother with the child, they will have to pay for this with their lives. ${ }^{63}$

One interesting feature of this ordinance is a reference to unlicensed midwives who try to sneak in at births. ${ }^{64}$ They are not condemned out of hand but are permitted at births if in addition a sworn midwife is present.

Another, somewhat later, ordinance from Heilbronn in Swabia requires midwives to call in a physician for difficult births. ${ }^{65}$ Midwives are not allowed to perform embryotomies or Caesareans without the presence of a physician; that is, those procedures that involve the use of instruments are now removed from their area of competency. ${ }^{66}$ Neither are they allowed to give their patients fragrant waters, balm, or compresses, these remedies being the prerogative of the physician. A latefifteenth-century addition to the ordinance stated that midwives had to report illegitimate births and abortions to the city government.

The ordinance from Württemberg (I480) discussed in Chapter I gives explicit instructions on how to perform a Caesarean and clearly stipulates the possible survival of the mother. In Germany, it seems, where midwives were subjected to official control much earlier than in France, their areas of competency were not limited as severely. 
The late fifteenth-century ordinance from Nuremberg, analyzed in detail by Merry Wiesner, fixed the fees for midwives (comparable to those of a skilled craftsman) and forbade married women to enter the profession, probably because they were assumed to be too busy with their own families to do their job adequately. From Wiesner's analysis a picture of the typical midwife emerges: "She was a widow, or an older, unmarried woman, not especially well-off financially as she did not have her own household. The fact that admonitions against married midwives continued indicates that not all were of the marital status considered proper, however."67

In none of the early German ordinances do we find any remarks on the training and education of midwives. That they were supposed to learn from older and more experienced colleagues is mentioned in passing, but no specific requirements are enumerated.

Unlike in Germany, in France ordinances regulating midwifery (and thus the "controlled midwife") did not appear until Is60, and this late date may explain the more stringent measures regarding the training and examination of prospective midwives. Richard Petrelli has summarized the course of instruction: midwives with the best reputations were given the title of matrones jurées and were in charge of the apprenticeships of future midwives. Paris had four such matrones. When the applicant had completed her apprenticeship successfully, the matrone issued a certificat de capacité. This certificate was then submitted to the king's chief barbersurgeon or his lieutenant and to the priest of the parish. Some theoretical training, offered by the sworn surgeons, was required in addition to the apprenticeship. ${ }^{68}$ Thus the midwives were allied with and dependent on the surgical confraternity of Saint Côme, a dependency that in Fasbender's opinion proved extremely harmful for the future of obstetrics. ${ }^{69}$ Fasbender does not elaborate on this statement, which is admittedly rather loaded. I believe that he refers to a growing tendency in the male practice of obstetrics of too-frequent surgical interventions and the overuse of instruments. Not for nothing was the man midwife of the eighteenth century referred to as the "Angel of Death."70 Through our own study we can confirm and clarify Fasbender's uneasy feelings. Male surgeons entered obstetrics via the Caesarean operation; thus the emphasis in the first deliveries performed by men was on a surgical procedure. As a consequence of this early preoccupation with surgical delivery on the part of physicians, surgical intervention became more and more a standardized option in childbirth. ${ }^{71}$ 
The midwif e's chances of getting a medical education consisting of more than observing other midwives at work were very small, and consequently her capacities, especially in the field of surgical delivery, were limited. There seems to be a correlation, however, between the issue of midwifery statutes and the surgical and medical activities allowed to midwives. Thus in France, as we saw in the illustrations, midwives were shown as extremely competent in performing postmortem Caesareans up to about 1400 . After that date, when Caesareans on living women seemed at least a possibility, men began to take over. The exclusionary and restrictive measures applied to French midwives are not formalized until much later. They become clearly visible only in the requirements spelled out in the different French ordinances from 1560 to the Revolution, which tended toward questioning and limiting the midwife's autonomy. In almost all of the sixteenth-century ordinances, midwives are required to seek the assistance of a doctor for any birth presenting the slightest difficulty or complication. Regulations fixed in writing thus postdate actual practices by many years. Based on the iconographic evidence, we can conclude that the male takeover of surgical delivery was well under way by the beginning of the fifteenth century.

The late medieval and Renaissance ordinances from France and Germany offered a clear picture of the midwife's official duties and responsibilities. But what of their other, less official but nevertheless wellknown functions, such as providing contraceptives and performing abortions and infanticide? It in these areas that midwifery and witchcraft were believed to overlap and it was knowledge in these areas that contributed to the demise of the autonomous midwife.

\section{The Effect of the Witch-Hunts on WOMEN IN MEDICINE}

Women were the principal targets of the witch-hunters. Of more than a hundred thousand people executed during the witch-hunts, 85 percent were women. ${ }^{72}$ One type of woman proved particularly vulnerable to accusations of witchcraft: that of the old "hag," especially if she was a midwife. How did this stereotype of the witch develop? Theological, ideological, and sociological factors all contributed to the creation of a concept of "the witch."

Before 1500 , trials for witchcraft occurred in a pattern of peaks and 
valleys, with the first modest peak sometime between I3I5 and 1319 and two more significant peaks about the middle of the fifteenth century and again between $\mathrm{I} 48 \mathrm{O}$ and $\mathrm{I} 484 .{ }^{73}$ The last date marks the issuing of the bull "Summis desiderantes" by Pope Inncocent VIII. In it, he encouraged the two Dominican inquisitors Heinrich Institoris (or Krämer) and Jakob Sprenger to embark on a major witch-hunt. Two years later, the two inquisitors published the inf amous Malleusmaleficarum, which presented the misogynistic and antisexual trends of the witch-hunts in a concentrated form. The Malleus repeated and organized material from earlier handbooks and proved extremely influential in the subsequent development of similar texts. These texts reflect the learned tradition of witchcraft and witch-hunting (characterized by an insistence on demonic possession), a tradition which, as Richard Kieckhefer has made clear, must be distinguished from the popular one, which emphasizes evil deeds, or maleficia, perpetrated by individuals not necessarily in league with the devil. ${ }^{4}$

A survey of the major works on the witch-hunts shows that theories of witchcraft developed principally in those countries where the learned tradition prevailed and influenced the popular tradition. France and Germany produced a large number of learned treatises on witchcraft, England few. The witch trials themselves also developed differently in these countries. In England, for example, Keith Thomas and Alan Macfarlane have concluded, accusations of witchcraft were very localized, often linked to personal quarrels and revenge. ${ }^{75} \mathrm{~A}$ standard type of accusation involved people who begged at someone's door, were rebuffed, and left muttering curses. If a misfortune, however small, then struck a member of the household, the beggar would be blamed. Thus, as E. William Monter has shown, British scholarship emphasizes the crucial role of maleficia; in France, demonological possession came to the fore in showcase trials; in Germany, the emphasis was on panic trials, sometimes of gigantic proportions, which can be traced to the imperial custom of torturing suspects to have them identify their accomplice. ${ }^{76}$ The ripple effects of forced denunciations on a large scale, often by children, are easy to imagine.

Generalizations about the European witch-hunts are almost impossible to make. Each region had different characteristics, both in theory and practice. Often witches were burned as scapegoats for specific misfortunes. A plague epidemic in Constance, for example, came to an end only when it was believed that all witchcraft in the region had been de- 
stroyed. ${ }^{77}$ In other cases, especially the earliest ones in France, many persecutions had political motivations and thus did not single out women. ${ }^{78}$ Also, in many regions a strong link existed between heresy and witchcraft, and some scholars believe that the witch-hunts were a natural consequence of the persecution of heretics. ${ }^{79}$ Given the large variety in the accusations, the methods of persecution, the types of punishment, the theoretical underpinnings, and the popular beliefs of witchcraft, any uniformity that can be found in all of Europe necessarily takes on special importance. As is well known, the most striking uniform feature of most witch-hunts was their preference for women.

Not all victims of the witch-hunts were women, of course. But Monter has shown that many of the men accused of witchcraft had some connection with suspicious women. He describes the sociological nexus of witchcraft in the Jura region: "Old isolated women; kinship to witches; proximity to witches"-here is the origin of the widening circle of accusations centering on a system that was built on the quick progression in a person's life from a dangerous reputation to accomplice of the devil and his disciples to demonic possession itself. ${ }^{80}$ Men were often believed to have been victimized by women and described themselves as having been seduced by witches, as having engaged in witchcraft at the instigation of their wives, for example.

Why were women believed to be more susceptible to witchcraft and why were they the principal victims? The witch-hunts were a means to rid society of threatening elements. Sometimes the threat consisted in the mere existence of a new sociological group. Midelfort shows that demographic changes and a growing tendency to marry later produced such a new group: single women. From $s$ percent before the sixteenth century, their percentage in the general population now rose to is-20 percent. At the same time, widows constituted to to 20 percent of the taxpayers. ${ }^{81}$ Monter stresses that these women posed a threat to the established order: "If we begin by emphasizing how often these accused witches were elderly widows or spinsters, we can argue that witchcraft accusations can best be understood as projections of patriarchal social fears onto atypical women, those who lived apart from the direct male control of husbands or fathers. These defenseless and very isolated women became the group most often exposed to charges of witchcraft." 82 But the sociological argument is not enough to explain the viciousness of the misogynism evident in the witch-hunts. Other factors were the deep-seated misogynism of the church fathers as well as the idea that women were psycholog- 
ically and physiologically inferior to men. ${ }^{83}$ The writers of the Malleus devote many pages to answering the question "Why is it that women are chiefly addicted to evil superstitions?" They do not deny the existence of good women. But they are few and far between (mostly in the Bible). Most women are governed by insatiable lust. Their extreme sexual hunger exposes them to the sexual advances of the devil and makes them his instrument. Only with the help of a demonic pact were women able to perform magic acts, for natural magic was out of their reach: women were considered much too stupid to have any insight into nature. ${ }^{84}$ Institoris and Sprenger assemble a large number of misogynistic commonplaces in question 6 of part I of their Malleus maleficarum. Their special scorn is reserved for midwives, "who surpass all others in wickedness." 85

This condemnation of midwives brings us to the questions that are most interesting for our present study: Why were midwives and female healers singled out for special persecution? Were all midwives suspected of being witches? Let us first consider the second question.

The Malleus did not condemn all midwives out of hand. Let us look at one of its many case histories: "[In Reichshofen] there was a most notorious witch, who could at all times and by a mere touch bewitch women and cause an abortion. Now the wife of a certain nobleman in that place had become pregnant and had engaged a midwife to take care of her, and had been warned by the midwife not to go out of their castle, and above all to be careful not to hold any speech or conversation with this witch." 86 Needless to say, the woman does not take her midwife's advice, leaves the castle, and runs into the witch, who places both hands on the pregnant woman's stomach. As the woman feels the child moving in pain, she returns to the castle where the midwife informs her that it is "already too late." And indeed, when the time for delivery comes, the woman gives birth not to a healthy child but to "separate fragments of its head and feet and hands." This horror was permitted by God to punish the woman's husband, who had not shown enough zeal in the prosecution of witches.

The events in this story are interesting from several points of view. First of all, it is typical for the Malleus that a woman should be the scapegoat for her husband's wrongdoing. Second, the punishment is linked to procreation or rather to the prevention of it. Third, the "good" midwife warns of the witch and later blames the disaster at the birth on the evil witch. One gets the impression that "witches" could serve as a 
kind of malpractice insurance for the good midwife. That is, since midwives were in a precarious situation if something went wrong during the birth they may have blamed other women whose reputations were questionable. In any case, this story points to a possible rivalry between midwives, which is also illustrated in another Malleus story. A pregnant woman from the vicinity of Strasbourg is approached by a midwife whom she does not trust. She "knew her bad reputation." To placate the untrustworthy midwife the woman falsely promises to request her services for the birth. But when her time comes she calls in a different midwife. A week after the birth the rejected midwife (now called a witch), accompanied by two other women, enters the new mother's room, curses her by touching her abdomen and by "replacing the woman's entrails." As predicted by the "witch," the woman suffers for six months and is then relieved of unclean matters (including brambles, bones, and thorns). ${ }^{87}$

Two important conclusions can be drawn from these stories. First, they aim to portray some sort of professional rivalry between different groups or types of midwives, and second, Institoris and Sprenger claim to believe in the existence of good midwives who could protect women against witches.

How can this conclusion be reconciled with the constant invectives against midwives in the Malleus? Clearly, Institoris and Sprenger posited two types of midwives. The good one was in charge of procreation and the protection of pregnant women. The bad one was the enemy of all procreation, for many of the crimes that witches were accused of related to sexual matters or procreation, that is, they made men impotent, incited people to adultery, deprived men of their reproductive organs, and practiced contraception, abortion, and infanticide.

The similarity between the skills of midwives and the supposed magic powers of witches has led to an equation of the midwife and the witch, which, in much of the scholarship on the subject, is made in too facile a manner. After all, the period of the witch-hunts coincides with the period of the first municipal ordinances and regulations for midwives. The city officials and honorable women in charge of formulating and enforcing these regulations did not think that they were dealing with witches. They did exhort midwives, however, not to use superstitious means. The central problem, then, seems to be one of control. The changes made in German midwifery ordinances from the mid-fifteenth to the sixteenth century show that a central concern was to control and to restrict mid- 
wives' activities. In addition to the performance of Caesarean section, several other previously accepted activities were now forbidden: dispensing medications, embryotomies of dead fetuses, the use of hooks or other metal instruments, certifying the death of mother and/or child, and finally, diagnosing the diseases through the examination of a patient's blood or urine, that is, all those skills by which surgeons and physicians believed they could distinguish themselves from midwives. ${ }^{88}$ As Birkelbach and her colleagues suggest, the regulation that a physician had to be called in at difficult births had no great practical value (since male physicians knew less about childbirth than midwives) but, rather, extended the area of male control over female midwives.

Through these ordinances as well as through accusations of witchcraft, the uncontrolled midwives and practitioners were marginalized, whereas those practitioners who upheld the prevailing antisexual and pro-birth ideology were integrated into the mainstream of society, albeit in inferior-and controlled-positions. It is clear how professionalization and witchcraft intersect: both achieved similar ends with regard to society as a whole and to the healing professions in particular: they marginalized women.

The special skills of midwives and female healers as they related to sexuality and procreation not only were assets used in the service of women's health but also threatened some of the most important values of medieval society: the family and male control over women. ${ }^{89}$ Contraception, abortion, and infanticide were some of the means women possessed to control their fertility, the size of their families, and consequently their lives. All of these means were of course condemned by the church, which is not to say, however, that they were not practiced. Let us take a brief look at each of them from a moral-historical perspective.

There are several types of sources for a study of contraception, abortion, and infanticide: religious writings (especially the penitentials), medical writings, and judicial records, such as pardons. All of these sources present their own problems. Medical writings generally belong to a learned tradition and are often far removed from the daily reality of medieval women. Pardons, on the other hand, give us a realistic glimpse of some of the hardships of a woman's life, but they deal, of course, mostly with crimes and thus do not generally include remarks on contraception. The penitentials, used as guidelines for confessors, point up some discrepancies between church theories and practice, since they are often more moderate than the official doctrines of the church and the 
punishment they mete out is often adapted to real-life situations. From this complex web of sources we will try to unravel those threads which are pertinent to the present study. 90

Contraception had been practiced since ancient times and no moral judgment was attached to descriptions of the various contraceptive methods in medical texts. In the New Testament (Gal. 5:20), however, Saint Paul condemned the use of pharmakeia, or drugs (often magical), and established a link between pharmakeia and licentiousness. In Revelation 21:8, fornicators are condemned right after pharmakoi. The term pharmaka, as John T. Noonan points out, "embraces potions used to affect life or birth." Despite these condemnations, the first three centuries of the Christian era saw few explicit statements on contraception. Influenced by the Stoic idea that all actions must have a well-defined purpose, the church posited that sexual intercourse can be justified only if it has a procreative purpose. In the fourth century, Saint Jerome described contraception as homicide ("Others, indeed, will drink sterility and will murder a man not yet born"), and Augustine listed offspring (proles) as one of the three goods of marriage. In Augustine's hierarchy of values, however, procreation comes only after fidelity and continence: having children spiritually is more valuable than having real children. ${ }^{91} \mathrm{Au}-$ gustine vehemently condemned "poisons of sterility" as destructive to the goods of marriage in a passage that was known throughout the Middle Ages as the Aliquando. ${ }^{92}$ Jerome's definition of contraception as homicide became the prevalent one, possibly because he used the expression drinking sterility, and most contraceptives were indeed potions. Another important milestone in the condemnation of contraception was a tenthcentury text (Si aliquis) by Regino of Prüm, which helped anchor the equation of contraception and homicide in canon law, an equation, however, that many considered excessive and that was not universally and at all times accepted. ${ }^{93}$ Nevertheless, in many penitentials contraception was referred to as maleficia, a term that also had connotations of pagan magic. Not only were the women who desired contraceptives condemned there: those aiding her in procuring them were just as guilty.

From ancient times certain types of maleficia had been linked to women. Women were accused of achieving their evil designs by poison, by the throwing of lots, by incantation, by the production and destruction of waxen images, and the like. Rendering men impotent was believed to be one of the specialties of the pagan and medieval striga, or 
witch. Personal jealousy and a desire for vengeance after being left by a lover supposedly moved two women in late-fourteenth-century Paris to cause male impotence by various ointments and waxen images. ${ }^{94}$ While the devil can physically remove the male member, ${ }^{95}$ witches habitually cast a "glamor" over it so that the men believe their penis has vanished. This technique is illustrated in the story of a young man of Regensburg who lost his member after breaking up with his girlfriend. When he consults a woman in a tavern about his problem she suggests that his girlfriend is a witch who has made his penis disappear. The young man returns to his girlf riend demanding the restitution of his member. The girl, naturally, claims total ignorance in this matter and "relents" only when the man is about to strangle her. She is thus persuaded to touch him between the thighs, saying, "Now you have what you desire." Immediately afterward the young man feels that his member has reappeared. ${ }^{96}$ One can see how the fear of impotence, a specifically male fear, would lead to belief in such a story. To have control over sexual performance meant also to have control over procreation. While impotence and sterility were feared by men as limiting their power, contraception could be seen by women as increasing their power. ${ }^{97}$ Based on such stories as the ones just cited the different meanings of maleficium fused semantically and, in the title of that most pernicious text of the witch-hunts, Malleus maleficarum, were clearly assigned to the female sex.

Women were in charge of most contraceptive means, but a distinction has to be made between sexual practices that may have a contraceptive effect (for example, oral or anal sex) and means that are designed only for contraception. ${ }^{98}$ In the early penitentials (up to 813), there are, according to Pierre Payer, no explicit condemnations of either contraceptive sexual practices or potions. But, of course, enough later canons existed that condemned any form of contraception. From J.-L. Flandrin's study, "Contraception, mariage, et relations amoureuses," it becomes clear that "unnatural acts", that is, those sexual practices that precluded procreation, were extremely widespread and vehemently censored by the church.

A variety of contraceptive means were available to medieval couples. The ancient and the Arabic medical traditions recommended talismans as well as various herbal spermicides, pessaries or suppositories (soaked, for example, in mint juice), and potions. Jumping backward (nine times) after intercourse may expel the seed. Fumigation with the smoke of a burning mule's hoof is also recommended. ${ }^{99}$ Most of the contraceptives 
are meant for women, but a few were meant for men, such as oiling the penis with cedar oil.

What is interesting in the transmission of contraceptive knowledge is the separation between the teachings of the church and the medical texts of the time. A striking example is Albertus Magnus, who gives no explicit recipes for contraceptives (although he mentions coriander, rue, and lettuce as anaphrodisiacs), but in his explanations of sterility becomes a fertile source for contraceptive knowledge (malgré lui, perhaps?). ${ }^{100}$ In any case, he keeps his moral judgments neatly separated from his medical teachings. ${ }^{101}$

Thus medieval attitudes toward contraception were ambiguous. Condemned unequivocally in the writings of the church, contraceptive means were transmitted in medical writings and in the popular tradition. According to Noonan, contraception was not a major social problem, since it was hardly mentioned in secular law. The major heresy that could have posed a threat to the perpetuation of the species, the Cathars, had been eradicated by 1260 . "There were economic reasons for individuals to limit births. But plague, famine, and war affected western Europe often enough in this period so that there was no serious population pressure. It [contraception] was practiced chiefly to avoid impoverishment." $102 \mathrm{Nev}$ ertheless, contraception continued to be proscribed, and it was not until the eighteenth century that the equation of contraception and homicide was banned from theological writings. ${ }^{103}$

These conclusions have by no means been universally accepted. The militant German scholars Heinsohn and Steiger try to refute Noonan's claim of the social unimportance of contraception. It was the possibility of depopulation, brought about by the fourteenth-century Great Plague, they claim, that turned contraception into a major threat to the ruling classes. The witch-hunts were predicated on the desire to assure the production of people. ${ }^{104}$ The proof that the authors provide for a carefully planned campaign for an increase of the labor force are minimal. Nevertheless, as I mentioned earlier, many of the accusations leveled against witches centered on the skills and functions of midwives.

Women who were accused as witches often lived on the margins of society. Married women were not persecuted as often as unmarried women. Now, one of the developments of the fifteenth century was a new theory, elaborated by Martin Le Maistre (1432-8I), on marital intercourse that posited that "not every copulation of spouses not performed 
to generate off-spring is an act opposed to conjugal chastity."105 Even though Le Maistre's views were slow to take hold, they eventually gained general acceptance. In practice this meant that a childless marriage was not immediately suspect. But the slightly looser interpretation of the condemnation of contraceptive means did not extend to extramarital intercourse and pregnancy. Again, we encounter the problem of control. The example cited earlier of controlled midwives versus uncontrolled midwives can now be supplemented by the opposition between controlled and uncontrolled intercourse. Witches were clearly associated with the latter and thus posed an extraordinary threat to established marriage. Sex outside of marriage must be punished, and any form of birth control would make it possible to remove the most certain proof of sinful conduct: children. Thus the production of children was not a value at all; the invective of Institoris and Sprenger was directed against those women capable of hiding, or helping other women hide, the consequences of their insatiable lust.

One of the main tenets of the Malleus was women's sexual insatiability and their consequent susceptibility to diabolical influences, specifically their desire to copulate with the devil. Hansen places Institoris and Sprenger's insistence on the sexual nature of diabolical possession in the context of ascetic and misogynistic currents of the later Middle Ages. ${ }^{106}$ If witches had (sterile) intercourse with the devil they naturally posed a threat to the goods of marriage. But again it seems that the campaigns against midwives who were believed to be witches were set in motion not primarily by a desire for the increase of population but rather because exaggerated, even morbid, views of sex led to the violent prosecution of those knowledgeable of contraceptive means. A consideration of one of the other supposed crimes of witches, infanticide, will clarify this position.

Pope Innocent's bull Summis desiderantes insisted that witches "cause to perish the off-spring of women."107 This indictment could refer to either abortion or infanticide. Two years later, Institoris and Sprenger specified the midwives' supposed crimes in part I, question II of the Malleus: "That witches who are midwives in various ways kill the child conceived in the womb, and procure an abortion; or if they do not this offer new-born children to devils. Here is set forth the truth concerning four horrible crimes which devils commit against infants, both in the mother's womb and afterwards. And since the devils do these things through the medium of women, and not men, this form of homicide is 
associated rather with women than with men." Interestingly, the authors go on to describe natural means of contraception, such as certain herbs, which do not belong to the province of witches. Unnatural acts, including abortion, miscarriage, and the devouring of children, are ascribed to the midwife-witches. Institoris and Sprenger conclude, "No one does more harm to the Catholic Faith than midwives."108 And at the height of the witch-hunts, one of the preeminent inquisitors, Henri Boguet, posed a question similar to that found in the Malleus: "How do midwives, if they are witches, kill the children they deliver?"109 At a trial in Briançon in 1437 the precise description of an infant's murder in his cradle would provide an answer to Boguet's question. The child was killed; his body was then mixed with "nightly pollutions," menstrual blood, and pubic hair and used for ritual purposes. 110 This last point is crucial, for it distinguishes infanticide by witches from that committed by other women.

Evidence for the practice of infanticide exists for many different regions and centuries, but most of it involves cases of mothers who killed their own infants. Forced by social and economic pressures, many women apparently saw no other solution. Emily Coleman, in "Infanticide in the Early Middle Ages," based on the ninth-century polyptych of Saint Germain-des-Près, has shown that infanticide was practiced as a means of population control. The victims were mostly female. This also holds true for fifteenth-century Florence, where the proportion of surviving girls was abnormally low. ${ }^{111}$ In every respect, infanticide was a female crime. The principal offender was the unwed mother. Since midwives were obliged by law to report any illegitimate births, their help was not sought by unmarried pregnant women. Efforts to conceal pregnancies and to dispose of the evidence - the babies-led to horrifying crimes of despair. In "L'infanticide à la fin du moyen âge," Brissaud lists a large number of cases of infanticide, many of them heartbreaking examples of the isolation and helplessness of lower-class women. Some women baptized their infants before killing them, a practice that would reduce their punishment if they were found out but that also may have helped assuage their mental anguish. The discovery of a dead baby usually led to extensive searches for the guilty woman; these searches involved the intimate examination of suspected women and bore some resemblance to the witch-hunters' search for the witches' mark, a degrading and sexually charged procedure. ${ }^{112}$

Since the time of Charlemagne infanticide had been treated as homicide. Under the reign of Saint Louis a first offense of involuntary infan- 
ticide, such as accidentally suffocating a child in bed with its parents, was punished by prison, but a repeat offender would be punished by death: she would be burned or buried alive. ${ }^{113}$ From the pardons issued to women guilty of infanticide one gets a slightly less grim picture. If a woman was too young to know what she was doing, if the child died accidentally or was born dead, if penances were already imposed (such as a pilgrimage to Rome), if she had children who needed her or if she promised to marry the father of the child-in all these cases clemency might be expected. 114

There are important differences between the cases of infanticide just discussed and the often fantastic accounts of infanticide supposedly committed by witches. The fact that poverty was one of the most frequently cited extenuating circumstances in the penitentials seems to indicate that mothers could expect at least some sympathy if their motives were economic. On the other hand, a prostitute who wanted to hide her "perversity" by killing her child had no hope for leniency. ${ }^{115}$ Similarly, for witches, no extenuating circumstances could be cited, but here because of the belief that their killing of children involved sexually perverse rituals. The ingredients listed in the above-mentioned trial at Briançon give us some idea of how the witch-hunters imagined these rituals. The witches' brew was a sexual brew and led, in the inquisitors' imagination, to orgies of copulation with the devil.

Midwives, then, are condemned because they are women and as such ready to submit sexually to the devil; but they also possess the sexual expertise that allows them to control men and other women. They assume control not only over their own reproductive functions but also over those of their victims. And it is exactly this control that municipal ordinances on midwifery are designed to wrest away from women. As Merry Wiesner has shown, "midwives appear most often in the city council records (Ratsbücher) in connection with criminal cases, particularly abortion and infanticide," which they were obliged to report. ${ }^{116}$ Midwives were thus employed to spy on and denounce the unfortunate women who had to bear the shame of an illegitimate pregnancy.

Midelfort points out that midwives formed one group of the population that was most often denounced by tortured suspects. ${ }^{117} \mathrm{He}$ does not attempt, however, to give any reasons for the notoriously bad reputation of midwives. The principal reason that midwives were feared and denounced was clearly their knowledge, or at least their claims to knowledge, of means and techniques relating to sexual performance, procrea- 
tion, and the prevention of procreation. But another reason for the popular dislike of midwives may have been their official function as spies in sexual matters for the authorities. Thus the midwives were caught between conflicting obligations. On the one hand, their task was to help and protect women and their offspring; but on the other hand, they had to betray and expose to severe punishment the weakest members of the group entrusted to their care. This supposed position of power contributed to the midwives' downfall.

No other campaign in history was so clearly directed against women as the witch-hunts. Especially for women in medicine the long-term effects of the witch-hunts were disastrous. Given the state of medieval medicine, diagnosis and therapy were tentative at best, and it was easy to ascribe medical failures to the evil charms of witches. Women could be removed from positions of control and power without much ado, and most women were probably wary of assuming such positions even if they had the chance to do so. It is hardly surprising therefore to find "few female medical practitioners" in the sixteenth century, as Estienne Pasquier remarked. 118

\section{Special Problems of Caesarean Birth}

As early as the fourteenth century, before the theoretical crystallization of the image of the witch, women were accused of stealing stillborn babies or of killing newborns by their touch. ${ }^{119}$ In cases of Caesarean birth, the conditions for these supposed crimes must have been considered ideal. The mother would most likely be already dead when the child was delivered; the family might be in such distress that they would not pay attention to what happened to the baby. But, most important, the decision of whether to perform a Caesarean at all would be up to the midwife. Thus the midwife had more power in the extraordinary circumstances of Caesarean birth than in those of normal childbirth, where her position would be at best that of an auxiliary.

One of the most frequently cited accusations against midwives was that the newborn had died unbaptized. The same accusation was leveled against supposed witches. In the 1437 trial at Briançon, one of the principal points of the prosecution was that the child was sine baptismo defunct[us]. ${ }^{120}$ In 1587 , a midwife confessed to a whole series of crimes against unborn and newborn children. In every case, the midwife spec- 
ified, the devil forced her to kill the children before they were baptized. ${ }^{121}$ These crimes were considered especially heinous because it was the medieval midwife's responsibility to see to it that the newborn was baptized. ${ }^{122}$ The city of Nuremberg even composed a special baptism ordinance that was distributed to midwives. ${ }^{123}$

Now, we recall that those canons of various church councils that dealt with Caesarean birth laid a special stress on the midwif e's obligation to perform baptism. The situations in which a Caesarean was indicated were clearly the most critical ones, resulting as they did in the death of the mother and frequently of the child. More than in normal births, then, mothers and children involved in Caesarean births were at the mercy of the midwife. Not only the possible physical salvation of the child but its spiritual salvation as well lay in her hands alone. It now becomes clearer why male surgeons replaced female midwives in Caesarean birth earlier than in normal childbirth. One of the motivations that prompted the male takeover was the distrust of midwives. Would they perform their duties as to the baptism of the newborn? The answers to this question ranged from doubtful to negative, since as early as the second half of the fourteenth century executions for the killing of unbaptized infants are reported. 124

In addition to the supposed worry about the spiritual welfare of mother and child, professional rivalries and the efforts on the part of established male physicians and surgeons to control female medical practitioners played the largest roles in the marginalization of women. Theological and medical-professional reasoning go hand in hand for the problems associated with Caesarean birth. An examination of two midwives' ordinances from 1452 and 1552 (printed in I555) confirms these points. ${ }^{125}$ As outlined above, the changes show a systematic restriction of the midwives' activities. The Caesarean section plays a central role here. The 1452 ordinance specifies that the midwife, should she feel in need of help for a Caesarean, should call in an especially qualified woman. The motivation for the composition of the ordinance (the "disorder" [unordnung]) may imply that midwives hesitated in the performance of a Caesarean: believing the mother to be still alive they apparently refused to perform a Caesarean in time for the child to be baptized. Thus Caesarean section is one of the most sensitive issues in this context. Accordingly, the sixteenth-century ordinance specifies that a doctor der artzney, that is, a male physician, must be called in for a Caesarean. He is 
now in charge of Caesareans and any other deliveries involving the use of surgical instruments, which midwives are no longer allowed to use. ${ }^{126}$

Together with the fact that the control of midwives was now in the hands of the city council (as opposed to the "honorable women" of the first ordinance) this male takeover of Caesarean sections marked a decisive step in the marginalization of midwives.

Caesarean birth is useful as a touchstone for an investigation into the marginalization of women in medicine because the developments described in this chapter can be observed first in the context of that operation and in the images depicting it. For centuries, male obstetrical intervention was characterized by the use of instruments, which became a symbol of the supposed male superiority in terminating a difficult birth. ${ }^{127}$ It was in the context of Caesarean sections that the male prerogative regarding the use of instruments was spelled out explicitly for the first time.

In a period when the consequences of the Great Plague led to tightening requirements in the medical profession and, at the same time, to a search for scapegoats in society, women had to relinquish their places of relative autonomy and authority in the healing professions. ${ }^{128}$ The same two currents that have been studied separately as consequences of the fourteenth-century plague combined forces and resulted in the demotion of medical women. The professionalization of medicine and the witchhunts worked together to ensure male control over women in medicine. ${ }^{129}$ Through the marginalization of midwives and their knowledge of contraception, men claimed control over women's reproductive functions, a control they have been slow to relinquish. Thus, in the fourteenth century, the seeds were planted for ideas and attitudes that still affect women today. 